International Journal of Life Sciences
Available online at http://sciencescholar.us/journal/index.php/ijls
Vol.3 No. 1, March 2019, pages: $31 \sim 40$
e-ISSN: 2550-6986, p-ISSN: 2550-6994
https://doi.org/10.29332/ijls.v3n1.255

\title{
Risk Factors in Ecosystem of Hawksbill Turtles (Eretmochelys Imbricata) from Ila Playita of Machalilla National Park
}

\author{
(C) CrossMark

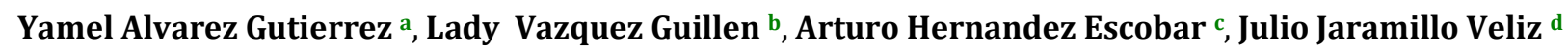 \\ Article history: Received 18 July 2018, Accepted: 31 December 2018, Published: 16 March 2019
}

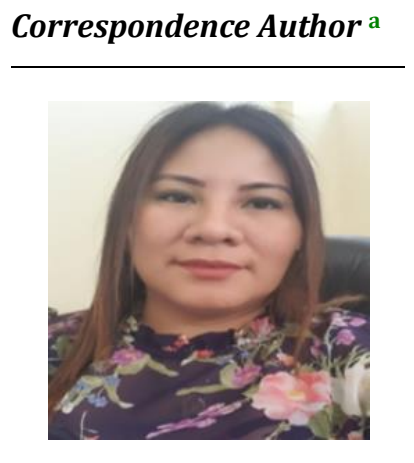

Keywords

balance;

habitat;

hawksbill;

risk factors;

turtle;

\begin{abstract}
The results of research work are presented, which was carried out under a nonexperimental, cross-sectional and descriptive design. The objective was to diagnose the presence of risk factors in the habitat of Hawksbill turtles, in the Machalilla National Park. Observation methods, document analysis, induction deduction and interview techniques were applied to officials of the referred institution. Biotic and abiotic factors were evaluated and the results were subjected to the corresponding statistical processing. It is identified that although in the environmental order the studied habitat collects ideal conditions, factors of biotic origin that threaten the balance of that environment subsists.
\end{abstract}

e-ISSN: 2550-6986, p-ISSN: 2550-6994@C Copyright 2019. The Author. SS Journals Published by Universidad Técnica de Manabí. This is an open-access article under the CC BY-SA 4.0 license (https://creativecommons.org/licenses/by-sa/4.0/) All rights reserved.

\section{Contents}

Abstract

1. Introduction.

2. Materials and Methods.

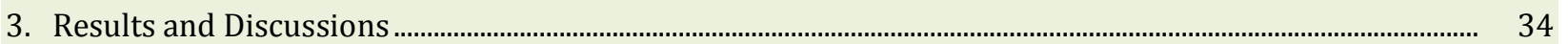

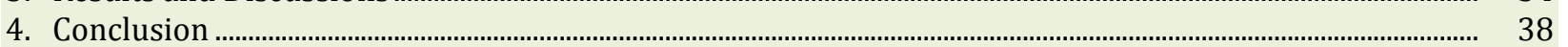

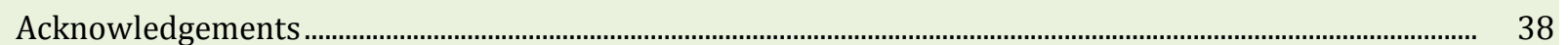

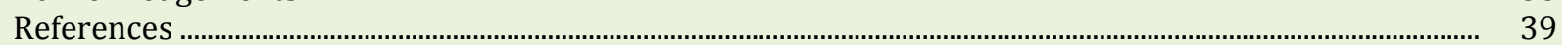

a Master in Administration Environmental, Universidad Estatal del Sur de Manabi, (UNESUM), Jipijapa, Manabi, Ecuador

b Environmental engineer, Universidad Estatal del Sur de Manabi, (UNESUM), Jipijapa, Manabi, Ecuador

c Ph.D. in Pedagogical Sciences Universidad Estatal del Sur de Manabi, (UNESUM), Jipijapa, Manabi, Ecuador

d Universidad Estatal del Sur de Manabi, (UNESUM), Jipijapa, Manabi, Ecuador 


\section{Introduction}

The Hawksbill Turtle, whose scientific name is Eretmochelys imbricata, is one of the three marine species, of the order of the chelonians, that nest in Ecuador. They arrive at the Machalilla National Park in the month of November and in the months of December, January, February, and March carry out the incubation and hatching of the eggs. This species contributes to the regulation of the overpopulation of jellyfish and algae and also constitutes a tourist attraction.

There is the opinion that some factors are manifest that could be affecting their habitat and, therefore, the number of individuals of this species, as well as their growth, within the Machalilla National Park. The Machalilla National Park is recognized globally.

The Playita (Little Beach) site is located in its surroundings, a very recognized site for the presence of the marine species of hawksbill turtles, which nest in tropical and subtropical zones appearing in areas of coral reefs and rocky areas and reaches maturity in a period of 20 to 40 years. Therefore, we must pay attention to the risk factors that may threaten the existence of this species in the mentioned site.

The number of visitors to the National Park flora and fauna of the place and environmental components may be elements that act negatively on the species balance required for stability, mainly in relation to their nesting and habitat. For this reason, it is essential to identify the dynamics of the risk factors that can negatively affect Hawksbill turtles.

In the search for information about the Hawksbill turtles, it has been noted that highlights the interest and concern for the conservation and recovery of the marine turtle of the species Carey, considered in danger of extinction (Campbell, 2014).

On the other hand, the Inter-American Convention for the protection and conservation of marine turtles (IAC), It has assigned a high priority to the subject with the objective of prioritizing and directing the necessary actions to ensure the recovery of the Hawksbill turtles, before the great threats that occur in their different habitats.

The Machalilla National Park is located in the central-western area of the coastal region of the country; Park covers an area of 56,184 hectares comprising a land portion (approximately 41,754 ha) and marine $(14,430$ ha.) (Miller, 1980).

The latter includes islands, islets, rocky outcrops, coral reefs, beaches, and impressive cliffs; there the marine currents converge: warm of the Child, cold of Humboldt and the Equatorial Countercurrent. Miller (1980), what favors the existence of unique ecosystems, with high biodiversity and variety of species. Hawksbill turtles (Eretmochelys imbricata) are very complex and specialized marine reptiles. It is considered that to mature, reach adulthood, reproduce and complete the life cycle, they need a diversity of means, in particular, terrestrial beaches, the open sea, and coastal and estuarine waters. During a normal life cycle, the turtles disperse and migrate; they travel long distances, often thousands of kilometers, usually traveling to the high seas, which includes the territorial waters of different countries. Mora (2005), The rate of growth varies according to size and places, however, they are very slow and this causes turtles to take a decade to mature.

According to studies by Dick, B., Hawksbill turtles have the following characteristics: "They have a relatively narrow head with two pairs of prefrontal scales. Its carapace has an oval shape, thick and overlapping shields, a markedly serrated posterior margin and four pairs of costal shields "(Dick, 2005).

In terms of size, the Hawksbill turtle "is one of the smallest, reaching up to $90 \mathrm{~cm}$. of length and $80 \mathrm{Kg}$ of weight. Their front fins are of medium length compared to those of other species; they also have two nails in each fin "(Pritchard, 2005).

According to Soria, "the Hawksbill Turtle is found mainly in tropical areas and, to a lesser extent, in subtropical waters of the Atlantic, Indian and Pacific Oceans. They are migratory with complex routes crossing very different habitats throughout their lives ... "(Soria, 2008).

The Hawksbill turtle is the most tropical of all sea turtle species. Being found mainly in tropical and subtropical waters, it appears in areas of coral reefs, rocky areas, estuaries, and coastal lagoons. It is found mainly in the Caribbean Sea, the northern Gulf of Mexico, the Greater and the Lesser Antilles and through Central America southward to Brazil. In the Eastern Pacific it has been observed in the Gulf of California and the states 
of northwestern Mexico and from the Central American coasts to Colombia and Ecuador in South America (Chacon, 2008).

In the Eastern Pacific it has been observed in the Gulf of California and the states of northwestern Mexico and from the Central American coasts to Colombia and Ecuador in South America (Chacon, 2008).

The studies carried out by Campbell (2014), indicate, as main threats, the following:

a) Egg collection

b) Direct capture of individuals (legal and illegal),

c) Loss of habitat (mainly due to coastal development),

d) Incidental capture"

On the other hand, the environmentalist Baquero notes that the extraction of sand "negatively impacts the nesting of turtles at various points along the coast • Slaughter of nesting females (Baquero, 2008).

The Ecuadorian continental coast has undergone a process of urbanization that has negatively affected the nesting of sea turtles by altering the beaches and generating light pollution. The degradation of the marine habitat in Ecuador is also produced by the exploitation, production, refining, and transportation of oil, in Figure 1, it is shown Characteristics of the La Playita (Little Beach).

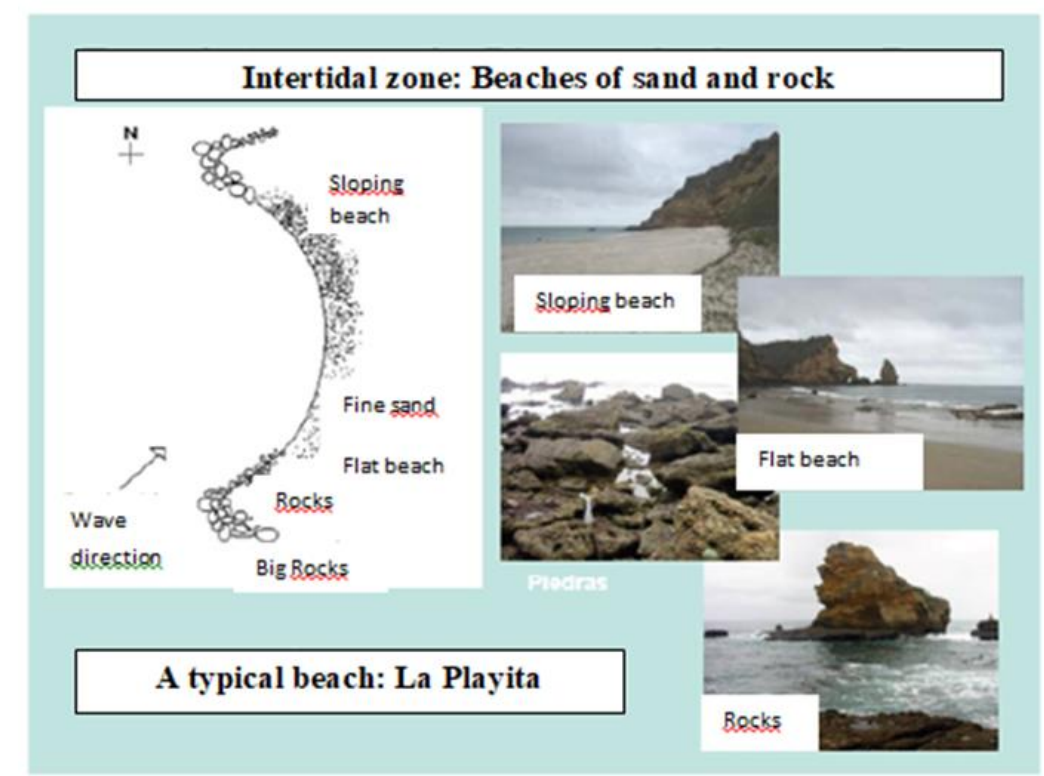

Figure 1. Characteristics of the La Playita (Little Beach) site, in the Machalilla National Park Source: Machalilla National ParkSource: Machalilla National Park

Harmful algal blooms can cause the mortality of sea turtles. In 1999 there were several discolorations; Between April and May of that year the fishermen of the beaches reported reddish patches, and at the end of April they mentioned having observed some sea turtles dead (Herrera, 2008). In Figure 2, it is observed the geographical location of the Machalilla National Park

Gutierrez, Y. A., Guillen, L. V., Escobar, A. H., \& Veliz, J. J. (2019). Risk factors in ecosystem of hawksbill turtles (eretmochelys imbricata) from ila playita of machalilla national park. International Journal of Life Sciences, 3(1), 


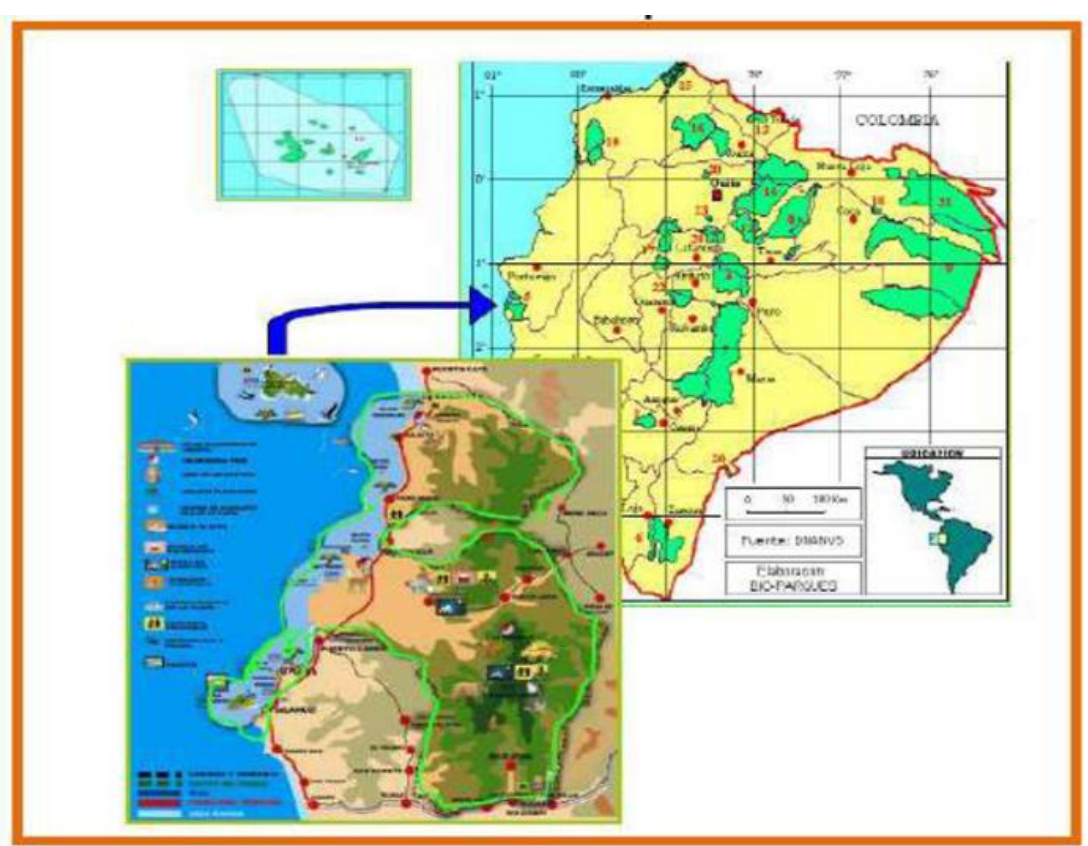

Figure 2. Geographical location of the Machalilla National Park Source: Machalilla National Park

\section{Materials and Methods}

The research, defined as non-experimental, cross-sectional and descriptive, was developed in the period between November 2016 and March 2017, at the site called La Playita (Little beach), located in Machalilla National Park. As a source of fundamental information, 30 members of the association Asopescar, who serve as guides and park rangers, were employed. Through observation, compliance with the actions foreseen in the research protocol was controlled.

The theoretical background was achieved by reviewing various sources, including books, scientific journals, web pages, interviews, environmental and conservation projects. The information obtained was processed using statistical methods and presented in tables and figure.

\section{Results and Discussions}

The assessment of the dynamics of the indicators selected to be controlled in the research process is presented individually, for better understanding, although it must be understood that its effect on the habitat of the Hawksbill turtles is developed in an integral manner. In the graph of Figure 3, it is an observed representation of the behavior of the physical impacts suffered by turtles in the marine environment. 


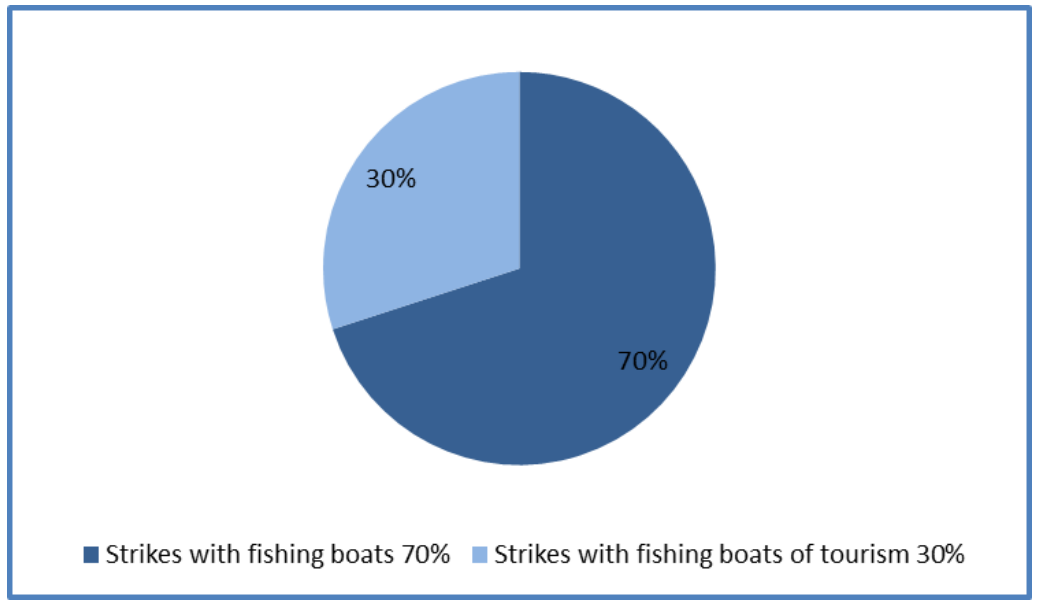

Figure 3. Graphical representation of the behavior of the physical impacts suffered by turtles in the marine environment

The data reflected in Graph No. 3 show that the greatest number of impacts suffered by individuals of the species studied derive from the action of boats that carry out fishing activities. It should be noted that although the boats that carry out tourist activities only have as their purpose the observation, almost a third of the impacts have these media as responsible for them, which warns about the need to increase the preparation of the drivers of these ships and their occupants about the care and attention to apply to preserve this species.

The information presented in figure 4 made it possible to identify the clear predominance of plastic compounds in the composition of solid waste located in the context of the habitat of the Hawksbill turtles in the Machalilla National Park.

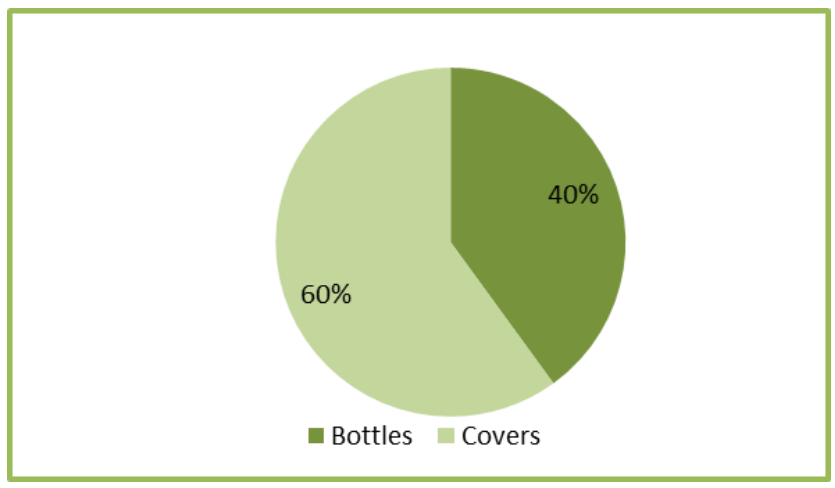

Figure 4. Types of solid waste of greater prevalence in the habitat of Hawksbill turtles

This situation indicates the presence of a risk factor that can affect, in an important way, the life behavior of the Hawksbill turtle in the studied environment and demands the increase of attention for its significant reduction or total elimination. In the graph in figure 5 shows the most frequent problems that affect the Hawksbill turtles in the marine habitat.

Gutierrez, Y. A., Guillen, L. V., Escobar, A. H., \& Veliz, J. J. (2019). Risk factors in ecosystem of hawksbill turtles (eretmochelys imbricata) from ila playita of machalilla national park. International Journal of Life Sciences, 3(1), 31-40. https://doi.org/10.29332/ijls.v3n1.255 


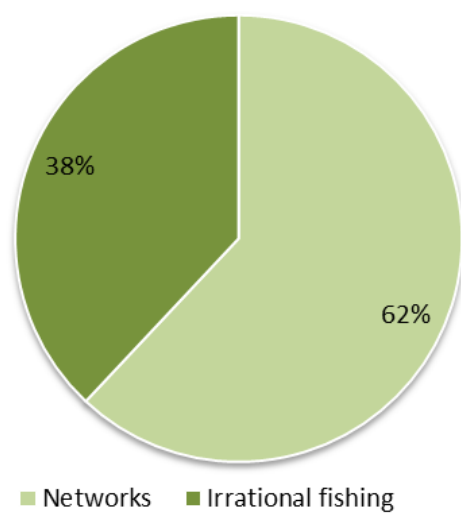

Figure 5. Most frequent problems that affect the Hawksbill turtles in the marine habitat

In figure 5, the results of the assessment of the problems faced by the Hawksbill turtle in the marine habitat are presented. It is striking that the presence of networks in the marine environment exceeds, due to the risks involved, furtive fishing. The first of the demonstrations, carried out within the framework of legality, requires greater advice and control; in the second case, it is necessary that the planned legislation be applied with greater rigor. These aspects can enhance the degree of attention to the species and reduce, to a large extent, the risks detected in Figure 6.

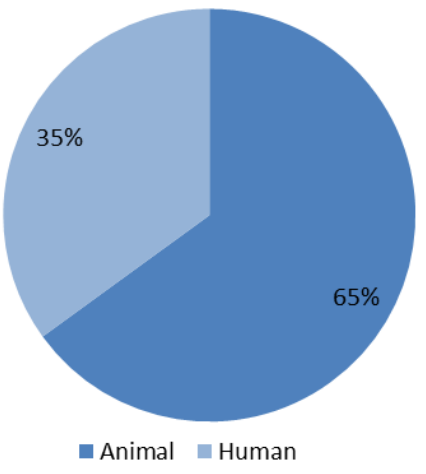

Figure 6. The behavior of the predation towards the Hawksbill turtles in the Machalilla National Park

In Figure 6, it is reflected that, according to the data obtained, in the habitat of the Hawksbill turtles, in the Machalilla National Park, predation is not a risk factor, it is a reality that is manifested both by the action of animals and for human beings. This is manifested in turtle nesting, as crabs and rats damage turtle eggs, seagulls, black rats, and herons also attack turtles in their early stages of life. Human action is also present, which depredates this species for food, religious or medicinal purposes.

In Table 1 you can see the threats of biotic factors on the habitat of Hawksbill turtles 
Table 1

Threats of biotic factors on the habitat of Hawksbill turtles

\begin{tabular}{clc}
\hline FACTOR & \multicolumn{1}{c}{ DETAIL } & THREAT \\
\hline FLORA & $\begin{array}{l}\text { Plants and shrubs typical of the area (Realito Monte salado, } \\
\text { Barbasco, Sebastian, Virola, Ficus among others) }\end{array}$
\end{tabular}

WILDLIFE Pelicans, gray seagull, frigate, ghost crab black-headed vulture, Predation of crabeater night heron, snail, squirrel, southern fruit bat, snake nests vine, boa kills horse, chameleon, pearl shell, branched coral, white hedgehog, black coral, Locust

Source: Guides of the Machalilla National Park

According to the interview with specialists from the Machalilla National Park (Guillen, 2018), it can be concluded that the flora found within the study site does not mean, in any way, a risk factor for the turtles. However, according to Guillem (2017), in the fauna there is a great variety of animals that, for the most part, cause damage; in some cases, they generate lesions, both on the skin and on the shell of the turtle; others are predators of nests, such as crabs and rats, or the case of seagulls, rats, and herons attack small turtles. In Table 2 , shows threats of abiotic factors on the habitat of Hawksbill turtles.

Table 2

Threats of abiotic factors on the habitat of Hawksbill turtles

\begin{tabular}{|c|c|c|}
\hline \multicolumn{3}{|r|}{ Abiotic factors } \\
\hline Factor & Values & Description \\
\hline Temperature & $21 c^{\circ}$ to $30 c^{\circ}$ & $\begin{array}{l}\text { The temperature at La Playita (Little Beach) is normal for } \\
\text { nesting turtles and their residence. }\end{array}$ \\
\hline Weather & Humid Tropical & $\begin{array}{l}\text { The climate is favorable for nesting turtles, including the } \\
\text { P.N.M has monitored that several turtles have returned to } \\
\text { this site several times for their nesting. }\end{array}$ \\
\hline Surface & $449 \mathrm{~km}^{2}$ & \\
\hline Height & 0 - 800 masl & \\
\hline Latitude & 1.558964 & \\
\hline Length & -80.810935 & \\
\hline Sea & Light green & $\begin{array}{l}\text { The beach is approximately } 1 \mathrm{~km} \text { long, its water is very } \\
\text { clean, the waves big and the beach is inclined. } \\
\text { Within the beach, there is the nesting of } 3 \text { types of turtle } \\
\text { species. } \\
\text { It is surrounded by secondary dry forest, in parts with light } \\
\text { hills and covered with thorny mountain vegetation. }\end{array}$ \\
\hline Humidity & $\begin{array}{l}\text { November / } 16 \\
\text { to March / } 17\end{array}$ & Ideal \\
\hline
\end{tabular}

Table 3

Shows the environmental impacts on the hawksbill ecosystem (Eretmochelys Imbricata)

\begin{tabular}{lll}
\hline \multicolumn{2}{c}{ Cause } & Effect \\
\hline $\begin{array}{lll}\text { Predation } & \text { of } & \text { Birth of a smaller number of turtles. } \\
\text { nests } & & \text { Turtles with strong injuries }\end{array}$
\end{tabular}

Gutierrez, Y. A., Guillen, L. V., Escobar, A. H., \& Veliz, J. J. (2019). Risk factors in ecosystem of hawksbill turtles (eretmochelys imbricata) from ila playita of machalilla national park. International Journal of Life Sciences, 3(1), 31-40. https://doi.org/10.29332/ijls.v3n1.255 
Marine Garbage Solid and metallic waste. The plastic bags and remnants of nets are the main source of marine debris because the turtles swallow them or get tangled and then they suffocate, they also ingest plastic pieces obstructing the digestive channel causing infections and obstruction in the turtles. The turtles also absorb chemical contaminants from the plastic, which can alter their reproduction

Degradation of Pollutants from terrestrial sources such as domestic, industrial and agricultural the marine waste affect the state of health of turtles, accumulating pesticides and heavy metals habitat contaminating their immune system making them susceptible to infections and diseases.

Fishing activity Turtles can get caught in shrimp trawls. Also in artisanal fishing, it occurs mainly with gillnets and longlines (this happens with an influx in the months of December to March). Interaction with hooks can cause turtle mortality when swallowed and lesions are reproduced in the digestive tract, or when they produce severe injuries in another part of the body that disables the turtle.

Incidental The decrease in the number of turtles

capture

Tourist boats The turtles collide and blow in the head, carapace.

Source: Machalilla National Park Fishermen of the area

The valuations derived from the information presented in the tables and graphs above indicate, as factors of the greater real and potential impact on the habitat of the Hawksbill turtles to the following:

a) The depredation of nests, which causes the reduction of the number of births of individuals of this species and to the survivors the tare with strong injuries.

b) Marine garbage, such as plastic bags and traces of nets that cause turtles to get tangled up or swallow them, causing suffocation or obstruction of the digestive tract.

c) The chemical contaminants present in plastic articles, which alter reproduction, as well as those present in household, industrial and agricultural waste that contribute pesticides and heavy metals, which contaminate the immune system.

d) Turtles can be trapped in shrimp trawls, gill nets, and long lines, being the time of greatest danger during the months of December to March; Hooks can cause mortality in turtles or severe injuries in another part of the body that disables the turtle, in terms of tourist boats the turtles are prone to collide causing blows to the head, carapace.

\section{Conclusion}

The most relevant results of the investigation are the following:

Within the marine habitat the Hawksbill turtles, in the Machalilla National Park there are still factors of risks and real affectations that, due to their impact, harm the individuals of this species causing severe damages, often irreversible, the turtles suffer blows with the boat fishing or tourism, causing them less serious and serious physical injuries, which require the necessary rehabilitation treatment.

It is established that, from the abiotic point of view, the habitat of the Hawksbill turtles gathers ideal conditions for the balanced development of the studied species; however, from the biotic angle, although the flora does not represent any risk, the fauna component generates the presence of risk factors that must be monitored to guarantee the stability of the habitat.

\section{Acknowledgments}

The work team is thanked for collaborating in the development of the research in a protected area of the country. 
References

Balazs, G. (2000). Factors to consider in marking sea turtles. Research and management techniques for the conservation of marine turtles, 116-125. (vol. 4). K. B. in Eckert,Ed.

Baquero, GA, Muñoz, JP, \& Peña, MM (2008). Identification of sea turtle nesting beaches on the coast of Ecuador and its main threats. First evidence of nesting in ten beaches in the country. Ecuador. Unpublished.

Campbell, C. L., \& Lagueux, C. J. (2005). Survival probability estimates for large juvenile and adult green turtles (Chelonia mydas) exposed to an artisanal marine turtle fishery in the western Caribbean. Herpetologica, 61(2), 91-103.

Chacón, D., Dick, B., Harrison, E., Sarti, L., \& Solano, M. (2008). Manual sobre técnicas de manejo y conservación de las tortugas marinas en playas de anidación de Centroamérica. Secretaría Pro Tempore de la Convención Interamericana para la Protección y Conservación de las Tortugas Marinas (CIT), San José, Costa Rica.

De Las Mercedes, Á. G. Y. (2015). Geographical Characterization of Three Hawksbill Turtle Nesting Sites (Eretmochelys Imbricata) in the Machalilla Puerto López National Park (Master's thesis, University of Guayaquil, Postgraduate Management, Master's Degree in Environmental Administration)Available electronically in http://repositorio.ug.edu.ec/handle/redug/26370

Ecuador, C. P. (2014). Coding of the Forestry Law and Conservation of Natural Areas and Wildlife. Forest and Conservation Law for Natural Areas and Wildlife, 405. Quito, Ecuador.

Guillem, V. C. L. (2018). factors and impacts in the ecosystem of the carey turtles (eretmochelys imbricata) of the beach of the machalilla national park. Bachelor Thesis. Jipijapa-unesum.

Herrera, M. (2008). Mortality of sea turtles recorded in the coasts of the Provinces of Guayas and Manabí in Ecuador. In Proceedings of the II Sea Turtle Symposium in the South Eastern Pacific. Lima-Peru (pp. 84-91).

Troëng, S., Chacón, D., \& Dick, B. (2004). Possible decline in leatherback turtle Dermochelys coriacea nesting along the coast of Caribbean Central America. Oryx, 38(4), 395-403.

Gutierrez, Y. A., Guillen, L. V., Escobar, A. H., \& Veliz, J. J. (2019). Risk factors in ecosystem of hawksbill turtles (eretmochelys imbricata) from ila playita of machalilla national park. International Journal of Life Sciences, 3(1), 


\section{Biography of Authors}

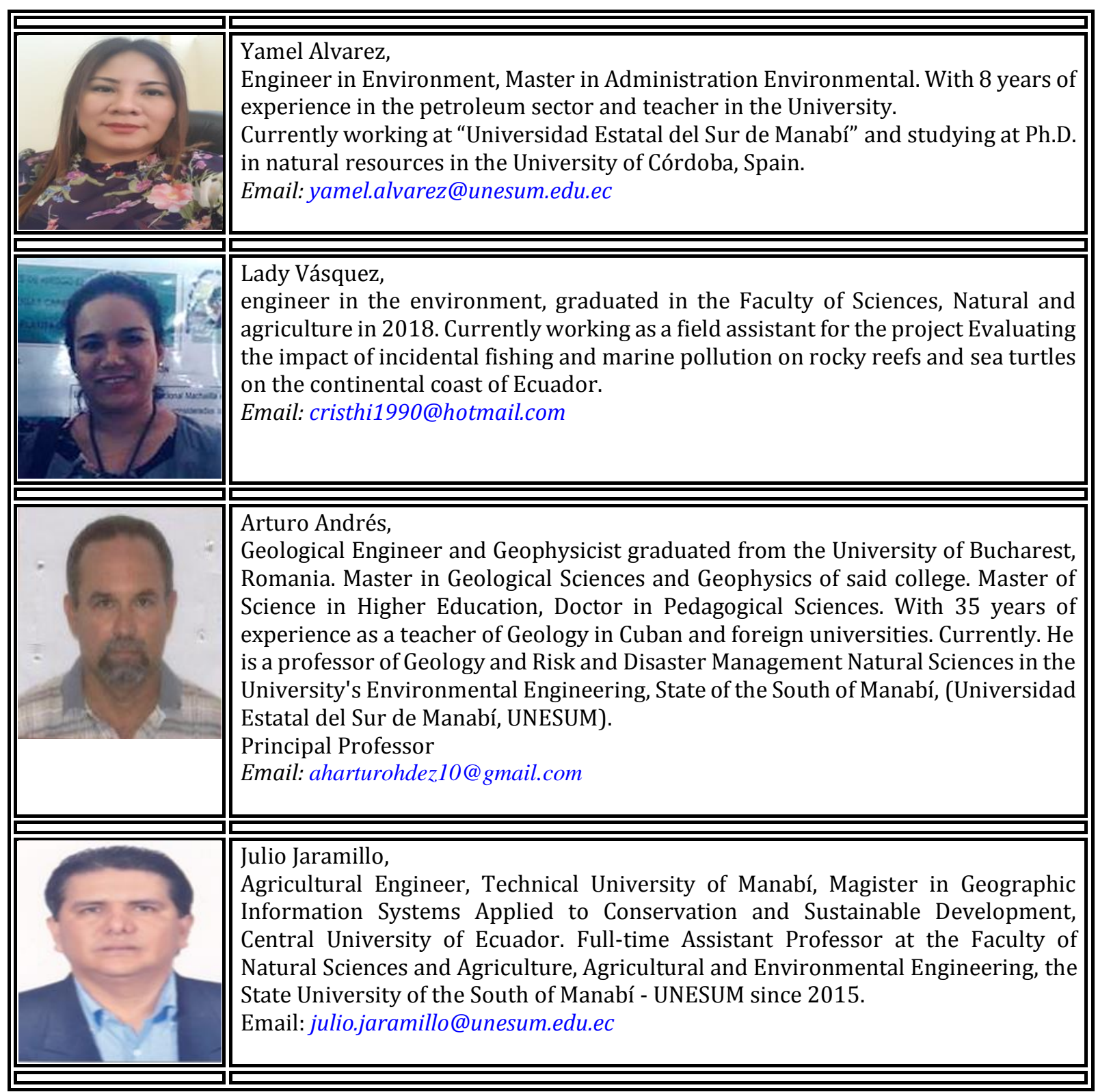

